\title{
KINERJA BIDANG BINA MARGA PADA DINAS PUPR-PKPP PROVINSI RIAU DALAM PERBAIKAN JALAN PROVINSI DI KABUPATEN ROKAN HULU
}

\author{
'Lisna Triwanti Zebua, ${ }^{2}$ Zaili Rusli \\ 1,2Program Studi Administrasi Publik Fakultas IImu Sosial Dan Politik, Universitas Riau \\ e-mail correspondence: lisnatriwanti@gmail.com, Zailirusliwdzr@Yahoo.co.id \\ Pekanbaru, 2893, Indonesia
}

\begin{abstract}
The road maintenance division at the PUPR-PKPP Office of Riau Province is a government agency that is authorized and responsible for repairing provincial roads throughout Riau Province, one of which is Rokan Hulu Regency. Rokan Hulu Regency has $504 \mathrm{~km}$ of provincial roads with a total road damage of $117.99 \mathrm{~km}$. Road damage in Rokan Hulu Regency has experienced many complaints from the public, so that the community considers the Bina Marga Division at the PUPR-PKPP Office of Riau Province to ignore road damage in Rokan Hulu Regency. The purpose of this study was to determine the performance and obstacles of the Highways Sector in repairing provincial roads in Rokan Hulu Regency. The research method used is qualitative research with descriptive analysis. The data needed are primary and secondary data derived from observations, interviews, and documentation which are analyzed by researchers so as to obtain accurate and clear data. The results of this study indicate that the performance of the Bina Marga Sector in carrying out road repairs in Rokan Hulu Regency is good, but there are several obstacles in the implementation of the work, namely the lack of APBD funds to carry out repairs and natural factors that can hinder the implementation of the road repair program.
\end{abstract}

\section{Keywords: Performance; Road Repair}

\begin{abstract}
Abstrak
Bidang Bina Marga Pada Dinas PUPR-PKPP Provinsi Riau merupakan instansi pemerintah yang berwenang dan bertanggung jawab terhadap perbaikan jalan provinsi di seluruh Provinsi Riau salah satunya kabupaten Rokan Hulu. Kabupaten Rokan Hulu memiliki jalan Provinsi sepanjang $504 \mathrm{Km}$ dengan total kerusakan jalan sepanjang 117,99 Km. Kerusakan jalan di kabupaten Rokan hulu banyak mengalami keluhan dari masyarakat, sehingga masyarakat menilai Bidang Bina Marga pada Dinas PUPR-PKPP Provinsi Riau mengabaikan kerusakan jalan di Kabupaten Rokan Hulu. Tujuan penelitian ini adalah untuk mengetahui kinerja dan hambatan Bidang Bina Marga dalam melakukan perbaikan jalan provinsi di Kabupaten Rokan Hulu. Metode penelitian yang digunakan adalah penelitian kualitatif yang bersifat analisis deskriptif. Data yang diperlukan adalah data Primer dan Sekunder yang berasal dari Observasi, wawancara, Dokumentasi yang dianalisis oleh peneliti sehingga mendapatkan data yang akurat dan jelas. Hasil dari penelitian ini menunjukkan bahwa kinerja Bidang Bina Marga dalam melakukan perbaikan jalan di Kabupaten Rokan Hulu sudah baik, namun terdapat beberapa kendala dalam pelaksanaan pekerjaan yaitu minimnya Dana APBD untuk melakukan Perbaikan serta faktor alam yang dapat menghambat pelaksanaan program perbaikan jalan.
\end{abstract}

\section{Kata Kunci: Kinerja; Perbaikan Jalan}

Open Access at:http://ojs.uho.ac.id/index.php/PUBLICUHO/index Journal Publicuho is licensed under a Creative Commons Attribution 4.0 International License. 


\section{Journal Publicuho}

ISSN 2621-1351 (online), ISSN 2685-0729 (print)

Volume 5 Number 1 (February - April 2022) pp. 152-162

Accredited SINTA SK.NOMOR 28/E/KPT/2019

Open Access at:http://ojs.uho.ac.id/index.php/PUBLICUHO/index

\section{PENDAHULUAN}

Infrastruktur merupakan aset fisik yang berpengaruh penting dalam peningkatan kualitas hidup dan kesejahteraan manusia. Hal tersebut dikarenakan sarana infrastruktur mempunyai peran yang sangat penting dan berpengaruh dalam menunjang pertumbuhan ekonomi masyarakat Indonesia. Untuk memberikan pelayanan yang maksimal kepada masyarakat, Pemerintah melakukan berbagai upaya untuk memberikan infrastruktur yang baik serta memadai kepada masyarakat yaitu dengan melakukan program pembangunan, perbaikan ataupun pemeliharaan jalan.

Dinas PUPR-PKPP Provinsi Riau khususnya Bidang Bina Marga Provinsi Riau memiliki tanggung jawab dalam hal pembangunan dan perbaikan infrastruktur Jalan, bidang Bina Marga mempunyai tugas menurut Peraturan Gubernur nomor 61 Tahun 2019, menyelenggarakan perumusan kebijakan, koordinasi, fasilitas, pelaksanaan, pemantauan, evaluasi dan pelaporan pada sekretariat, Bidang Pembangunan dan Peningkatan, Bidang Pemeliharaan dan Bidang Bina Teknik, serta menyelenggarakan kewenangan yang diberikan Pemerintah kepada Gubernur sesuai dengan peraturan perundang-undangan. Dalam hal ini jalan yang di maksud adalah Jalan Provinsi.

Kabupaten Rokan Hulu merupakan salah satu kabupaten di Provinsi Riau. Berdasarkan surat keputusan (SK) Gubernur Riau Nomor Kpts.308/IV/2017 tentang penetapan ruas jalan menurut statusnya sebagai jalan provinsi di Provinsi Riau menetapkan Sebanyak 11 ruas jalan dengan panjang jalan 504 km di Kabupaten Rokan Hulu sebagai jalan provinsi yang terbagi dalam kondisi baik, sedang, rusak ringan, dan rusak berat.

Tabel 1. Kondisi jalan provinsi di Kabupaten Rokan Hulu

\begin{tabular}{clcc}
\hline \multirow{2}{*}{ No } & \multirow{2}{*}{ Kondisi Jalan } & Panjang Jalan Provinsi (Km) & Persentase (\%) \\
\hline 1. & Baik & 329,29 & 65,38 \\
\hline 2. & Sedang & 56,3 & 11.17 \\
\hline 3. & Rusak Ringan & 19 & 3.77 \\
\hline 4. & Rusak Berat & 98,99 & 19,65 \\
\hline & Total & 503,58 & 100 \\
\hline & Sumber : Dokumen Data Dasar Prasarana Jalan Provinsi Dinas PUPRPKPP Provinsi \\
& &
\end{tabular}

Berdasarkan data diatas dapat diketahui bahwa jalan provinsi di kabupaten Rokan Hulu masih banyak mengalami kerusakan dan membutuhkan perawatan agar dapat menekan jumlah jalan yang mengalami kerusakan. Berikut ini adalah nama ruas jalan Provinsi di kabupaten Rokan Hulu serta perbandingan persentase kerusakannya, yaitu : 
ISSN 2621-1351 (online), ISSN 2685-0729 (print)

Volume 5 Number 1 (February - April 2022), pp.152-162

Lisna Triwanti Zebua, Zaili Rusli DOI: http://dx.doi.org/10.35817/jpu.v5i1.22862

Tabel 2. Nama Ruas Jalan Dan Persentase Kerusakan Jalan Provinsi di Kabupaten Rokan Hulu

\begin{tabular}{|c|c|c|c|c|}
\hline \multirow[b]{2}{*}{ No. } & \multirow[b]{2}{*}{ Nama Ruas Jalan Provinsi } & \multirow[b]{2}{*}{$\begin{array}{l}\text { Panjang } \\
\text { Jalan Provinsi }\end{array}$} & \multicolumn{2}{|c|}{ Persentase Kerusakan } \\
\hline & & & $\begin{array}{l}\text { Panjang } \\
\text { Jalan } \\
\text { Rusak }\end{array}$ & Persentase \\
\hline 1. & Tandun - Pasir Pangaraian & 61,6 & $2,2 \mathrm{Km}$ & $3,57 \%$ \\
\hline 2. & Pasir Pangaraian - Batas Sumut & 48,92 & $1,7 \mathrm{Km}$ & $3,48 \%$ \\
\hline 3. & Rokan - Pendalian - Dusun Batas & 23,23 & $9.13 \mathrm{Km}$ & $39,3 \%$ \\
\hline 4. & Ujung Batu - Rokan - Batas Sumbar & 69,33 & $29,8 \mathrm{Km}$ & $42,98 \%$ \\
\hline 5. & Pasir Pangaraian Tangun - Batas Sumut & 21.18 & - & - \\
\hline 6. & Dalu - Dalu - Mahato & 47,3 & $7.6 \mathrm{Km}$ & $16,06 \%$ \\
\hline 7. & Simp. Suram - Simp. Bagan 7 - Sontang & 73,72 & $44,6 \mathrm{Km}$ & $60,49 \%$ \\
\hline 8. & Simpang Kumu - Kota Tengah & 34,43 & $1,7 \mathrm{Km}$ & $4,94 \%$ \\
\hline 9. & Kota Tengah - Sontang & 37,81 & $2.2 \mathrm{Km}$ & $5,81 \%$ \\
\hline 10. & Sontang - Simpang Jurong - Duri & 59 & $14,7 \mathrm{Km}$ & $24,91 \%$ \\
\hline & $\begin{array}{l}\text { Ujung Batu - Kota Lama - Simpang } \\
\text { Bagan } 7\end{array}$ & 27,06 & $4,36 \mathrm{Km}$ & $16,11 \%$ \\
\hline
\end{tabular}

Sumber: Dokumen Data Dasar Prasarana Jalan Provinsi Dinas PUPRPKPP Provinsi Riau Tahun 2020

Berikut tabel anggaran perencanaan perbaikan jalan Provinsi di kabupaten Rokan hulu dari jumlah anggaran pemeliharaan jalan pada bidang bina Marga PUPR-PKPP pada Tahun 2020 sebesar Rp 12.480.840.503,00

Tabel 3. Anggaran perencanaan perbaikan jalan Provinsi di Kabupaten Rokan hulu

\begin{tabular}{lll}
\hline No. & Nama Ruas Jalan Provinsi & Anggaran \\
\hline 1. & $\begin{array}{l}\text { Pemeliharaan jalan tandun - pasir pangaraian } \\
\text { (1 Km berkala 15 Km Rutin) }\end{array}$ & Rp 4.950.000.000 \\
\hline 2. & $\begin{array}{l}\text { Pemeliharaan jalan ujung batu - rokan - batas } \\
\text { sumbar (1 Km Berkala 15 Km Rutin) }\end{array}$ & Rp 4.940.000.000 \\
\hline
\end{tabular}

Sumber: Dokumen Perencanaan anggaran preservasi jalan provinsi Dinas PUPR-PKPP Provinsi Riau Tahun 2020

Berdasarkan tabel diatas, dapat diketahui bahwa perencanaan perbaikan jalan pada tahun 2020 hanya dilakukan pada dua dari sebelas ruas jalan provinsi di kabupaten Rokan Hulu dengan target perbaikan jalan sepanjang $2 \mathrm{~km}$ dari 117,99 km jalan provinsi yang mengalami kerusakan, baik rusak ringan maupun rusak berat. Perencanaan perbaikan jalan yang memprioritaskan ruas jalan tandun - Pasir Pangaraian yang hanya memiliki kerusakan sepanjang 2,2 $\mathrm{km}$ menandakan kurang tepatnya sasaran dalam perbaikan jalan, hal tersebut dapat dilihat dari data kerusakan jalan pada tahun 2019 yaitu ruas jalan simpang Suram - Simpang Bagan 7 - Sontang dengan total jalan Rusak 46,4 Km lebih membutuhkan perbaikan di karenakan banyaknya jalan rusak pada ruas jalan tersebut. Sedangkan pada perencaan perbaikan ruas jalan Ujung Batu - Rokan batas - Sumbar dengan jumlah panjang 


\section{Journal Publicuho}

ISSN 2621-1351 (online), ISSN 2685-0729 (print)

Volume 5 Number 1 (February - April 2022) pp. 152-162

Accredited SINTA SK.NOMOR 28/E/KPT/2019

Open Access at:http://ojs.uho.ac.id/index.php/PUBLICUHO/index

jalan rusak 29,8 km sudah tepat sasaran, hal tersebut karena ruas jalan Ujung Batu - Rokan batas - Sumbar merupakan salah satu ruas yang memiliki total kerusakan jalan terpanjang setelah Simpang Suram - Simpang Bagan 7 - Sontang.

Perencanaan perbaikan jalan yang tidak seimbang dengan banyaknya kerusakan jalan di Kabupaten Rokan Hulu serta adanya ketidaktepatan dalam melakukan prioritas perbaikan sesuai dengan banyaknya kerusakan jalan pada setiap ruas jalan provinsi menyebabkan banyaknya keluhan dari masyarakat daerah Kabupaten Rokan Hulu kepada Bidang Bina Marga pada Dinas PUPR-PKPP Provinsi Riau yang menjadi penanggung jawab infrastruktur jalan provinsi di Kabupaten Rokan Hulu. Hal ini disebabkan karena kerusakan jalan tersebut dapat mempengaruhi perekonomian masyarakat serta meningkatnya kecelakaan lalu lintas. namun berdasarkan berita yang beredar dimedia massa hingga saat ini Dinas Pekerjaan Umum Provinsi Riau terkesan mengabaikan kerusakan jalan tersebut. sehingga hal tersebut bertentangan pada UU No. 22 Tahun 2009 pasal 24 ayat 1 tentang lalu lintas dan angkutan jalan, dimana penyelenggara wajib segera dan patut untuk memperbaiki jalan rusak yang dapat mengakibatkan kecelakaan lalu lintas.

Melihat latar belakang yang telah diuraikan diatas Peneliti tertarik untuk mengambil ruang lingkup Kinerja Bidang Bina Marga pada Dinas PUPR-PKPP Provinsi Riau dalam hal perbaikan jalan provinsi di Kabupaten Rokan Hulu. Selain sebagai evaluasi kinerja terutama pada bidang Bina Marga pada Dinas PUPR-PKPP Provinsi Riau juga sangat penting penelitian ini dilakukan untuk menjadi bahan evaluasi para administrasi Publik. Oleh karena itu, Penulis akan melakukan penelitian yang berjudul : "Kinerja Bidang Bina Marga pada Dinas PUPRPKPP Provinsi Riau dalam Perbaikan Jalan Provinsi di Kabupaten Rokan Hulu".

\section{METODOLOGI}

Penelitian ini dilakukan dengan jenis penelitian kualitatif yang bersifat analisis deskriptif. Menurut Sugiyono (2011 : 15) penelitian kualitatif adalah metode penelitian yang digunakan untuk meneliti pada kondisi objek yang alamiah, dimana peneliti adalah sebagai instrument kunci. Proses penelitian kualitatif melibatkan upaya - upaya penting, seperti mengajukan pertanyaan - pertanyaan dan prosedur - prosedur, mengumpulkan data yang spesifik dari partisipan, menganalisis data secara induktif dari tema - tema yang khusus ke tema - tema umum, dan menafsirkan makna data. Menurut Nazir dalam Andi Prastowo (201 1:186) Analisis Deskriptif merupakan suatu metode dalam meneliti status sekelompok manusia, suatu set kondisi, sikap serta pandangan terhadap suatu fenomena yang terjadi dalam masyarakat untuk menggambarkan data secara umum. Alasan peneliti menggunakan metode penelitian kualitatif yang bersifat analisis deskriptif adalah untuk mengungkapkan dan menggambarkan kejadian atau fakta, keadaan, fenomena, variable dan keadaan yang 
ISSN 2621-1351 (online), ISSN 2685-0729 (print)

Volume 5 Number 1 (February - April 2022), pp.152-162

Lisna Triwanti Zebua, Zaili Rusli DOI: http://dx.doi.org/10.35817/jpu.v5i1.22862

terjadi saat penelitian berlangsung dengan memberikan informasi yang terjadi sebanarnya tanpa menambah dan mengurangi.

\section{HASIL DAN PEMBAHASAN}

\section{Kinerja Bidang Bina Marga pada Dinas PUPR-PKPP Provinsi Riau dalam Perbaikan Jalan di Kabupaten Rokan Hulu.}

Kinerja organisasi adalah gambaran mengenai tingkat pencapaian pelaksanaan suatu kegiatan, program, kebijaksanaan dengan menggunakan sumber daya secara efektif dan efisien dalam mewujudkan sasaran, tujuan, visi dan misi organisasi.

Untuk melihat kinerja Bidang Bina Marga pada Dinas PUPR-PKPP Provinsi Riau dalam perbaikan jalan provinsi di Kabupaten Rokan Hulu, Peneliti menggunakan teori dari Dwiyanto (2006:50) dengan 5 indikator kinerja yaitu :

1. Produktivitas

2. Kualitas Iayanan

3. Responsivitas

4. Responsibilitas

5. Akuntabilitas

Kelima indikator tersebut merupakan poin - poin penting untuk menilai bagaimana kinerja Bidang Bina Marga pada Dinas PUPR-PKPP Provinsi Riau dalam melakukan perbaikan jalan Provinsi di Kabupaten Rokan Hulu.

\section{Produktivitas}

Produktivitas merupakan konsep untuk menentukan kemampuan Bidang Bina Marga pada Dinas PUPR-PKPP Provinsi Riau dalam melakukan perbaikan jalan di Provinsi di Kabupaten Rokan Hulu yang sesuai dengan keinginan masyarakat. Dalam rangka identifikasi produktivitas kinerja Bidang Bina Marga pada Dinas PUPR-PKPP Provinsi Riau dalam melakukan perbaikan jalan di Kabupaten Rokan Hulu dapat di lihat melalui beberapa aspek sebagai berikut :

\section{a. Kompetensi Sumber Daya Manusia}

Sumber daya manusia yang berkompeten merupakan sebuah hal yang harus dimiliki oleh suatu organisasi dalam memberikan pelayanan kepada masyarakat. Sumber daya manusia yang berkompeten merupakan salah satu faktor yang menentukan kinerja suatu organisasi, hal tersebut dapat diketahui dari semakin baik kompetensi yang dimiliki oleh sumber daya manusia akan menghasilkan produktivitas yang semakin tinggi sehingga dapat meningkatkan kinerja organisasi. Berdasarkan hasil penelitian yang dilakukan oleh peneliti, dapat diketahui bahwa kompetensi pegawai bidang bina marga pada Dinas PUPR-PKPP Provinsi Riau sudah baik dan sudah sesuai dengan kebutuhan organisasi, hal tersebut dapat dilihat dari keterampilan pegawai yang sudah bagus dan keahlian pegawai yang sudah 


\section{Journal Publicuho}

ISSN 2621-1351 (online), ISSN 2685-0729 (print)

Volume 5 Number 1 (February - April 2022) pp. 152-162

Accredited SINTA SK.NOMOR 28/E/KPT/2019

Open Access at:http://ojs.uho.ac.id/index.php/PUBLICUHO/index

sesuai dengan jabatan masing-masing.

\section{b. Ketepatan waktu}

Ketepatan waktu merupakan salah satu aspek dalam mengukur produktivitas suatu organisasi. Ketepatan waktu berkaitan dengan sesuai atau tidak nya waktu dalam penyelesaian pekerjaan dengan target waktu yang telah direncanakan. Berdasarkan hasil penelitianyang telah dilakukan oleh peneliti dapat diketahui bahwa Bidang Bina Marga pada Dinas PUPR-PKPP Provinsi Riau tepat waktu dalam melaksanakan tugas, namun terkadang terjadi keterlambatan dalam penyelesaian tugas misalkan karena curah hujan yang tinggi sehingga pekerjaan tidak dapat dilakukan.

\section{c. Kualitas Kerja}

Kualitas kerja merupakan suatu mutu produk yang dihasilkan oleh pegawai dalam melaksanakan tugasnya. Semakin baik kualitas pekerjaan yang dilakukan, maka semakin baik pula produktivitas organisasi tersebut. Berdasarkan hasil penelitian yang dilakukan oleh peneliti dapat diketahui bahwa kualitas kerja Bidang Bina Marga sudah baik terbukti dari dalam proses pelaksanaan pekerjaan, Bidang Bina Marga selalu melakukan pengecekan mengenai kelengkapan pihak kontraktor sebelum melakukan pekerjaan perbaikan jalan.

\section{Kualitas Layanan}

Kualitas layanan merupakan salah satu indikator untuk menentukan kinerja organisasi. Pandangan positif maupun pandangan negatif selalu muncul dari kalangan masyarakat apabila masyarakat merasa pelayanan yang diberikan oleh suatu organisasi tidak sesuai dengan harapan masyarakat, dan masyarakat merasa tidak puas akan pelayanan yang diberikan. Oleh karena itu, Bidang Bina Marga Pada Dinas PUPR-PKPP Provinsi Riau hendaknya mengetahui apa saja yang menjadi peran, tugas, ataupun wewenang untuk memberikan pelayanan kepada masyarakat, sehingga masyarakat merasa puas dengan kinerja dari Bidang Bina Marga tersebut. Berdasarkan hasil penelitian yang dilakukan oleh peneliti dapat diketahui bahwa Bidang Bina Marga pada Dinas PUPR-PKPP Provinsi riau dalam hal kualitas layanan sudah baik. Bidang bina marga selalu mengupayakan agar kondis jalan selalu baik namun hal tersebut tidak terlepas dengan anggaran yang tersedia, karena anggaran yang tersedia tidak akan cukup untuk memperbaiki semua jalan yang mengalami kerusakan, oleh karena itu Bidang Bina Marga melakukan prioritas perbaikan jalan, mulai dari perencanaan perbaikan jalan, anggaran yang digunakan hingga pada pelaksanaan pekerjaan dilapangan.

\section{Responsivitas}

Reponsivitas menurut Dwiyanto (2006:49) merupakan kemampuan suatu organisasi dalam mengenali, memahami, dan mengetahui kebutuhan masyarakat, yang kemudian menyusun agenda, membuat prioritas pelayanan, mengembangkan program - program sesuai 
ISSN 2621-1351 (online), ISSN 2685-0729 (print)

Volume 5 Number 1 (February - April 2022), pp.152-162

Lisna Triwanti Zebua, Zaili Rusli DOI: http://dx.doi.org/10.35817/jpu.v5i1.22862

dengan kebutuhan dan aspirasi masyarakat. Dapat diartikan bahwa responsivitas merupakan daya tanggap dan daya tangkap Bidang Bina Marga pada Dinas PUPR-PKPP Provinsi Riau dalam mengenali dan menanggapi keinginan serta apa yang dibutuhkan oleh masyarakat terkait jalan Provinsi yang ada di Kabupaten Rokan Hulu.

Penyampaian aspirasi maupun pengaduan mengenai Kinerja Bidang Bina Marga Pada Dinas PUPR-PKPP Provinsi Riau dapat dilakukan melalui layanan pengaduan yang telah disediakan oleh Dinas PUPR-PKPP Provinsi Riau, Layanan Pengaduan ini dapat di akses melalui link https://puprpkpp.riau.go.id/. Layanan pengaduan ini merupakan salah satu upaya untuk mempermudah masyarakat menyampaikan keluhan mengenai kerusakan jalan, sehingga bidang Bidang marga dapat lebih mudah mengetahui apa saja yang menjadi harapan serta kebutuhan masyarakat terkait jalan provinsi yang ada di Kabupaten Rokan Hulu.

Berdasarkan hasil penelitian yang dilakukan oleh peneliti dapat diketahui bahwa Bidang Bina Marga responsive dengan pengaduan - pengaduan masyarakat dan langsung melakukan tindakan perbaikan jalan dengan menurunkan alat berat dan mengirimkan material untuk memperbaiki jalan, namun Bidang Bina Marga pada Dinas PUPR-PKPP Provinsi Riau tidak dapat melakukan perbaikan di semua ruas jalan yang rusak, dikarenakan adanya keterbatasan anggaran.

\section{Responsibilitas}

Responsibilitas merupakan ukuran kinerja yang menunjukkan seberapa besar tingkat kesesuaian antara penyelenggara pemerintah dengan hukum atau peraturan dan prosedur yang telah ditetapkan. Untuk menilai responsibilitas pada Bidang Bina Marga Pada Dinas PUPR-PKPP Provinsi Riau dapat dilihat dari kesesuain Bidang Bina Marga dalam membuat perencanaan serta melaksanakan program perbaikan jalan dengan peraturan yang ada atau prosedur yang telah di tetapkan.

\section{a. Perencanaan}

Perencanaan merupakan tahap awal dalam menentukan bagaimana suatu organisasi merealisasikan atau mencapai tujuan organisasi tersebut. Bidang Bina Marga Pada Dinas PUPR-PKPP Provinsi Riau Dalam melakukan perencanaan dan membuat skala prioritas perbaikan jalan tentunya harus sesuai dengan peraturan atau prosedur yang ada. Berdasarkan hasil penelitian yang dilakukan oleh peneliti dapat diketahui bahwa dalam melakukan perencanaan perbaikan jalan sudah sesuai dengan peraturan yang ada, dan sudah mengikuti tahap - tahap sesuai dengan prosedur dalam melakukan perencanaan perbaikan jalan mulai dari melakukan survey kelapangan, menetukan kriteria penanganan jalan, mengajukan program, penilaian program serta pelaksanaan program sudah sesuai dengan aturan yang berlaku dan prosedur yang ada. 


\section{Journal Publicuho}

ISSN 2621-1351 (online), ISSN 2685-0729 (print)

Volume 5 Number 1 (February - April 2022) pp. 152-162

Accredited SINTA SK.NOMOR 28/E/KPT/2019

Open Access at:http://ojs.uho.ac.id/index.php/PUBLICUHO/index

\section{b. Pelaksanaan pekerjaan}

Pelaksanaan pekerjaan merupakan inti dari perencanaan yang telah dilakukan. Dalam melakukan Pelaksanaan Pekerjaan pada Bidang Bina Marga harus mengikuti dan sesuai dengan prosedur yang ada. Pelaksanaan pekerjaan di Bidang Bina Marga pada PUPR-PKPP Provinsi Riau tergolong dalam perbaikan atau penanganan jalan dengan system kontrak. Berdasarkan hasil penelitian yang dilakukan oleh peneliti dapat diketahui bahwa pelaksanaan pekerjaan sudah sesuai dengan aturan dan ketentuan yang berlaku. Ketentuan atau prosedur merupakan petunjuk teknis yang dikeluarkan oleh Dinas PUPR-PKPP Provinsi Riau untuk membuat pihak Bidang Bina Marga melakukan kegiatan perbaikan jalan secara tersusun dan sesuai dengan ketentuan yang berlaku. Hal ini bertujuan untuk memberikan pelayanan yang maksimal serta mensejahterakan masyarakat dalam bidang infrastruktur.

\section{Akuntabilitas}

Akuntabilitas merupakan kewajiban suatu organisasi untuk mempertanggungjawabkan keberhasilan atau kegagalan pelaksanaan kewenangan yang diberikan dibidang tugasnya. Pertanggungjawaban sangat diperlukan dalam sebuah organisasi hal tersebut berguna untuk mengontrol setiap pelaksanaan suatu program dalam organisasi supaya dapat mencapai tujuan dan sasaran yang telah ditetapkan. Akuntabilitas memiliki kaitan yang erat dengan pertanggungjawaban terhadap efektivitas pelaksanaan kegiatan atau program dalam mencapai sasaran atau target kebijakan yang telah ditetapkan. Dalam memberikan pertanggungjawaban dan keterangan kepada pihak yang memiliki kewenangan menerima pelaporan akuntabilitas dilakukan secara transparan atau terbuka. Hal ini bertujuan untuk menumbuhkan rasa kepercayaan penerima layanan dengan pemberi layanan. Berikut merupakan tabel pertanggungjawaban bidang bina marga dalam melakukan perbaikan jalan provinsi di Kabupaten Rokan Hulu.

Tabel 4. Akuntabilitas Kinerja Bidang Bina Marga dalam Perbaikan Jalan di Kabupaten Rokan Hulu

\begin{tabular}{|c|c|c|c|c|c|c|c|c|}
\hline \multirow[b]{3}{*}{ Kegiatan } & \multirow[b]{3}{*}{ Sasaran } & \multicolumn{7}{|c|}{ Realisasi Target } \\
\hline & & \multicolumn{3}{|c|}{ Keuangan } & \multicolumn{4}{|c|}{ Kinerja } \\
\hline & & Pagu & $\begin{array}{c}\text { Realisasi/ Capaian } \\
\text { Target }\end{array}$ & $\%$ & $\begin{array}{l}\text { Indikator } \\
\text { Kinerja }\end{array}$ & Target & $\begin{array}{c}\text { Realisasi/ } \\
\text { Capaian } \\
\text { Target }\end{array}$ & $\%$ \\
\hline $\begin{array}{c}\text { Pemeliharaan } \\
\text { jalan }\end{array}$ & $\begin{array}{c}\text { Lancarnya } \\
\text { Arus } \\
\text { Transportasi } \\
\text { dan } \\
\text { Pengguna } \\
\text { Jalan }\end{array}$ & 9.910 .000 .000 .00 & $9.153 .362 .133,40$ & 92 & $\begin{array}{c}\text { Terlaksananya } \\
\text { pemeliharaan } \\
\text { jalan }\end{array}$ & $\begin{array}{c}2 \text { Ruas } \\
\text { Jalan } \\
\text { dengan } \\
\text { panjang } \\
2 \mathrm{Km}\end{array}$ & $\begin{array}{c}2 \text { Ruas } \\
\text { Jalan } \\
\text { dengan } \\
\text { Panjang } \\
2,6 \mathrm{Km}\end{array}$ & 130 \\
\hline
\end{tabular}

Sumber :Bidang Bina Marga pada Dinas PUPR-PKPP Provinsi Riau Tahun 2020 
ISSN 2621-1351 (online), ISSN 2685-0729 (print)

Volume 5 Number 1 (February - April 2022), pp.152-162

Lisna Triwanti Zebua, Zaili Rusli DOI: http://dx.doi.org/10.35817/jpu.v5i1.22862

Berdasarkan hasil penelitian yang peneliti lakukan, dapat diketahui bahwa akuntabilitas Bidang Bina marga sudah baik, hal tersebut dapat dilihat dari tabel 3 yaitu realisasi yang diperoleh dalam melakukan perbaikan jalan melebih target yang telah ditentukan, kemudian pertanggung jawaban Bidang Bina Marga dapat dikatakan terjamin akan kebenarannya karena dalam melaksanakan pekerjaan, Bidang Bina Marga selalu memberikan laporan kepada pihak pengawas eksternal dan internal. Kemudian mengenai transparansi kepada masyarakat, Bidang Bina Marga pada Dinas PUPR-PKPP Provinsi Riau selalu transparan, hal tersebut terbukti dari proses lelang yang dilakukan oleh Bidang Bina Marga selalu dimasukkan ke Lembaga Pengadaan Secara Elektronik, lalu Bidang Bina Marga mempublikasikan dokumen yang dapat disampaikan kepada publik atau masyarakat, dan memasang papan informasi kegiatan pembangunan di sepanjang jalan yang dilakukan perbaikan di Kabupaten Rokan Hulu.

Faktor Penghambat Kinerja Bidang Bina Marga pada Dinas PUPR-PKPP Provinsi Riau dalam Perbaikan Jalan Provinsi di Kabupaten Rokan Hulu

\section{Keterbatasan APBD}

Terdapat kendala dalam pelaksanaan program Perbaikan jalan yaitu kurangnya anggaran untuk melakukan perbaikan jalan. melihat begitu banyaknya Ruas Jalan Provinsi di Kabupaten Rokan Hulu yang harus di perbaiki, serta kerusakan yang kerap terjadi dibeberapa ruas jalan mengakibatkan timbulnya ketidakseimbangan antara alokasi dana yang diberikan dengan banyaknya ruas jalan yang membutuhkan perawatan rutin maupun perawatan secara berkala. Hal tersebut mengakibatkan perbaikan jalan tidak dapat dilakukan secara acak, melainkan didasarkan pada urgensi atau kerusakan parah pada ruas jalan di wilayah tertentu. Urgensi yang dimaksud adalah kerusakan jalan yang memiliki pengaruh besar terhadap intensitas penggunaan jalan.

\section{Kondisi Tanah}

Kondisi tanah yang sering mengalami perbahan volume ketika musim penghujan maupun musim kemarau dapat mempengaruhi umur atau ketahanan fisik jalan, sehingga hal ini menjadi kendala bidang bina marga dalam melakukan perbaikan jalan.

\section{KESIMPULAN}

Kinerja Bidang Bina Marga pada Dinas PUPR-PKPP Provinsi Riau dalam melakUkan perbaikan jalan provinsi di Kabupaten Rokan Hulu sudah baik. Hal tersebut dapat diketahui dari lima indikator yang dipakai oleh peneliti mengenai kinerja bidang bina marga dalam melakukan perbaikan di Kabupaten Rokan Hulu. Pada indikator Produktivitas, sumber daya manusia pada Bidang Bina Marga sudah berkompeten dalam mengerjakan tugasnya, kemudian dalam pelaksanaan kegiatan program perbaikan jalan di kabupaten Rokan Hulu tepat waktu, dan kualitas kerja yang dilakukan juga sudah baik. hal ini menandakan dari sisi 


\section{Journal Publicuho}

ISSN 2621-1351 (online), ISSN 2685-0729 (print)

Volume 5 Number 1 (February - April 2022) pp. 152-162

Accredited SINTA SK.NOMOR 28/E/KPT/2019

Open Access at:http://ojs.uho.ac.id/index.php/PUBLICUHO/index

DOI: http://dx.doi.org/10.35817/jpu.v5i1.22862

Produktivitas kinerja Bidang Bina Marga sudah optimal. Pada Indikator Kualitas layanan dan Responsivitas sudah baik, karena Bidang Bina Marga selalu responsif terhadap pengaduanpengaduan masyarakat mengenai kerusakan jalan, dan bidang bidang Bina marga melakukan prioritas perbaikan jalan berdasarkan kebutuhan masyarakat. Pada indikator responsibilitas sudah baik, dalam tahapan melakukan perencanaan hingga pada pelaksanaan fisik dilapangan sudah sesuai dengan peraturan yang ada dan prosedur yang telah di tetapkan. Kemudian pada indikator akuntabilitas sudah bagus, Bidang Bina Marga transparan dalam proses pelaksanaan mulai dari proses lelang hingga pada pelaksanaan fisik di lapangan, bidang Bina marga juga selalu diawasi oleh pengawas Eksternal dan internal. Dalam pelaksanaan fisik dilapangan bidang Bina marga juga membuat papan nama kegiatan sehingga masyarakat mengetahui pekerjaan yang sedang dilaksanakan. Kemudian Bidang Bina Marga setiap tahunnya selalu memberikan laporan kerja mereka kepada Dinas PUPR-PKPP Provinsi Riau.

\section{REFERENSI}

Books:

Edison. 2016. Manajemen Sumber Daya Manusia. Bandung : Alfabeta

Fahmi, Irham. 2013. Manajemen Kinerja, Teori Dan Aplikasinya. Bandung : Alfabeta

Handoko, T. Hani. 2011. Manajemen Personalia Dan Sumber Daya Manusia. Yogyakarta : BPFE

Kodoatie J. Robert dan Roestam Sjarief. 2010. Tata Ruang Air. Yogyakarta : C.V Andi Offset Mahmudi. 2015. Manajemen Kinerja Sektor Publik. Edisi kedua. Yogyakarta : UPP STIM YKPN

Pasolong, Harbani. 2010. Kepemimpinan Birokrasi. Bandung : CV Alfabeta

Prastowo, Andi. 2011. Metode Penelitian Kualitatif Dalam Perspektif Rancangan Penelitian. Jogjakarta : Ar-Ruzz Media

Purhantara, Wahyu. 2010. Metode Penelitian Kualitatif Untuk Bisnis. Yogyakarta : Graha llmu

Sugiyono. 2011. Metode Penelitian Pendidikan Pendekatan Kuantitatif, Kualitatif, dan R\&D. Bandung : Alfabeta

. 2016. Metode Penelitian Kuantitatif, Kualitatif dan R\&D. Bandung : PT Alfabet

Tika, Pabunda. 2014. Budaya Organisasi dan Peningkatan Kinerja Karyawan. Jakarta : Bumi Aksara

Wibowo. 2016. Manajemen Kinerja, edisi kelima. Jakarta: PT Rajagrafindo Persada

Journal articles:

Elisabeth, Megaria. 2015. "kinerja dinas pekerjaan umum dalam pemeliharaan jalan dan jembatan di Kabupaten Toba Samosir". Vol 2 (1)

Ibrahim, W.H dan Idria Maita. 2017. Sistem Informasi Pelayanan Publik Berbasis Web pada Dinas Pekerjaan Umum Kabupaten Kampar. Jurnal ilmiah rekayasa dan manajemen system informasi. Vol 3(2) : 17-22. (DOI : http://dx.doi.Org/10.24014/rmsi.v3i2.4262 
ISSN 2621-1351 (online), ISSN 2685-0729 (print)

Volume 5 Number 1 (February - April 2022), pp.152-162

Lisna Triwanti Zebua, Zaili Rusli

DOI: http://dx.doi.org/10.35817/jpu.v5i1.22862

Mawarnaya, Robi. 2016. Pengawasan Infrastruktur Jalan Oleh Dinas Pekerjaan Umum Kota Pekanbaru. Vol 3(2)

Nur, A.Sri, A. Sihabuddin dan A.H Syadzily. 2019. Kinerja Pengelolaan Jalan dan Jembatan dalam Perspektif Pelayanan Publik pada Dinas Pekerjaan Umum dan Penataan Ruang Provinsi Banten Tahun 2017. Journal of Indonesian public administration and governance studies. Vol 3(1) : 448-469

http://dx.doi.org//10.31505/iipags.v3i1.5478

Rusliandy, H. Nurasa, Yogi S.S, dan Ridwan S. 2019. Hambatan Implementasi Sistem Merit Pada Dinas PUPR Kabupaten Bogor Dalam Pengelolaan Infrastruktur Jalan Kabupaten. Vol $13(1): 71-80$

URL : https://jurnal.bkn.go.id/index.php/asn/

laws and regulations:

UU No. 22 Tahun 2009 pasal 24 ayat 1 tentang lalu lintas dan angkutan jalan

Peraturan Gubernur Riau No 68 Tahun 2016 tentang Kedudukan, susunan organisasi, Tugas dan Fungsi, serta Tata Kerja Dinas Pekerjaan Umum dan Penataan Ruang Provinsi Riau yang kemudian mengalami perubahan menjadi peraturan Gubernur Riau No. 61 Tahun 2019 